\title{
Hakekat Manusia dan Implikasinya Pada Pendidikan Islam
}

\author{
MIFTAH SYARIF \\ Fakultas Agama Islam (FAI) Universitas Islam Riau (UIR) Pekanbaru \\ Jl. Kaharuddin Nasution, No. 113, Perhentian Marpoyan Pekanbaru 28284 \\ Email: miftah_syarif@fis.uir.ac.id
}

\begin{abstract}
Human nature in the concept of Islam is a creature created by Allah SWT, has a variety of potential to grow and develop towards the perfection. The implications of the Islamic concept of human nature and its relationship with Islamic education are: First, Islamic education system must be built on the concept of unity between qalbiyah and aqliyah in order to produce human intellectual and morals. Second, Islamic education should strive to develop the potential of human beings to the maximum, so it can be realized loaded hard skills and soft skills. Thirdly, Islamic education should be a conducive tool for the transformation of Islamic science and culture. Fourthly, the concept of human nature and the function of its creation in the universe must be fully accommodated in the formulation of Islamic educational theories through the apocalyptic, empirical and philosophical rationale of science. Fifth, the process of internalization of Islamic values into a person's person must be able to be integrated through the role of individuals and others (teachers), so as to strengthen the unity of the pattern and unity of purpose toward the formation of mental mentality insane kamil.
\end{abstract}

Keywords: Human Nature, Islamic Education

\begin{abstract}
Abstrak: Hakekat manusia dalam konsep Islam adalah makhluk yang diciptakan oleh Allah SWT, memiliki berbagai potensi untuk tumbuh berkembang menuju kepada kesempurnaan. Adapun implikasi konsep Islam tentang hakekat manusia dan hubungannya dengan pendidikan Islam adalah: Pertama, Sistem pendidikan Islam harus dibangun $\mathrm{di}$ atas konsep kesatuan antara qalbiyah dan aqliyah untuk dapat menghasilkan manusia intelektual dan berakhlak. Kedua, pendidikan Islam harus berupaya mengembangkan potensi yang dimiliki manusia secara maksimal, sehingga dapat diwujudkan bermuatan hard skill dan soft skill. Ketiga, pendidikan Islam harus dijadikan sarana yang kondusif bagi proses transformasi ilmu pengetahuan dan budaya Islami. Keempat, konsep hakekat manusia dan fungsi penciptaannya dalam alam semesta harus sepenuhnya diakomodasikan dalam perumusan teori-teori pendidikan Islam melalui pendekatan kewahyuan, empirik keilmuan dan rasional filosofis. Kelima, proses internalisasi nilai-nilai Islam kedalam pribadi seseorang harus dapat dipadukan melalui peran individu maupun orang lain (guru), sehingga dapat meperkuat terwujudnya kesatuan pola dan kesatuan tujuan menuju terbentuknya mentalitas insan kamil.
\end{abstract}

Kata Kunci : Hakekat Manusia, Pendidikan Islam 


\section{PENDAHULUAN}

Berulang kali protes dilontarkan para Malaikat, ketika Allah hendak menciptakan Adam sebagai bapak manusia yang akan berkembang turuntemurun di muka bumi. Berbagai argumen dan rayuan, bujukan dikemukakan, namun Allah ke Maha Kuasaan-Nya tetap menciptakan manusia. (Lihat QS. AlBaqarah : 30)

Hal ini dikarenakan Allah mencintai manusia, maka sebagai gantinya manusia harus membalas cinta Allah tersebut dengan berta'abbud dan bertaqarrub kepada-Nya. Inilah salah satu gambaran manusia yang ideal, dimana Al-Quran banyak berbicara tentang manusia sebagai salah satu makhluk yang unik baik secara fisik maupun psikis. Oleh karena itu, untuk mengetahui konsep Islam tentang kakekat manusia dengah berbagai poptensinya haruslah merujuk kepada wahyu yang diturunkan Allah kepada hambanya, karena Dialah yang menciptakan manusia.

Manusia merupakan makhluk ciptaan Allah yang paling sempurnya, dibandingkan dengan makhluk-makhlukNya yang lain. Kesempurnaan itu dimiliki oleh manusia, karena Allah memberikan keistimewaan berupa akal pikiran, yang tidak dimiliki oleh makhluk lainya. Disamping itu Allah juga melengkapi kesempurnaan manusia dengan memberinya daya hidup, mengetahui, berkehendak, berbicara, melihat, mendengar, berfikir dan memutuskan. Semua daya tersebut telah dibawa oleh manusia semenjak ia dilahirkan dalam keadaan fitrah, sebagaimana Hadits Nabi Muhammad SAW, كل مولود يولد على الفطرة فأبواه يهودانه أو ينصر انه أو

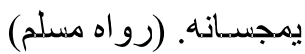

Artinya : Setiap anak dilahirkan di atas fitrahnya, makakeduaorang tuanya menjadikan dirinya beragama Yahudi, atau Nasrani, atau Majusi. (HR. Muslim)

Di dalam Al-Quran banyak ditemukan penjelasan yang menunjukkan tentang gambaran manusia baik secara biologis maupun psikologis, dan konsep tersebut akan dijelaskan dalam paparan berikut ini.

\section{KONSEP ISLAM TENTANG HAKEKAT MANUSIA.}

Ada empat ungkapan kata yang digunakan dalam Al-Quran untuk menunjukkan pada makna manusia dengan penekanan pengertian yang berbeda, yaitu :

\section{Al-Basyar}

Kata Al-Basyar dinyatakan dalam AlQuran sebanyak 36 kali dan tersebar kedalam 26 surat (al-Baqi, 1988: 153154). Secara etimologi al-basyar berarti kulit kepala, wajah, atau tubuh yang menjadi tempat tumbuhnya rambut. Pengertian ini menunjukkan makna bahwa secara biologis yang mendominasi manusia adalah pada kulitnya, dibanding rambut atau bulunya. Pada aspek ini terlihat perbedaan umum biologis manusia dengan hewan yang lebih didominasi bulu atau rambut (Ramayulis \& Samsul Nizar, 2011 : 48).

Al-Basyar juga dapat diartikan mulamasah, yaitu persentuhan kulit antara laki-laki dengan perempuan (Ibn Munzir, 1992 : 306). Secara etimologis dapat dipahami bahwa manusia merupakan makhluk yang memiliki segala sifat kemanusiaan dan keterbatasan, seperti makan, minum, seks, keamanan, kebahagiaan, dan lain sebagainya. Penunjukan kata al-basyar ditujukan Allah kepada seluruh manusia tanpa terkecuali. Demikian pula halnya dengan para rasulNya yang disebut sebagai manusia biasa, yang diberi wahyu kepada, sebagaimana Firman Allah SWT : 


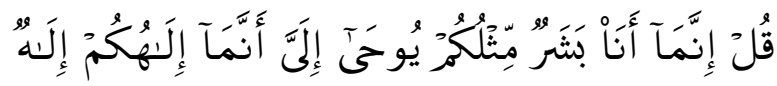

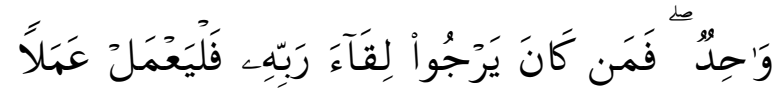

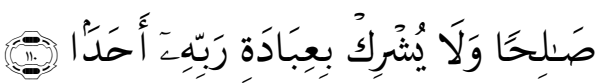

Katakanlah: Sesungguhnya aku ini manusia biasa seperti kamu, yang diwahyukan kepadaku: "Bahwa Sesungguhnya Tuhan kamu itu adalah Tuhan yang Esa". Barangsiapa mengharap perjumpaan dengan Tuhannya, Maka hendaklah ia mengerjakan amal yang saleh dan janganlah ia mempersekutukan seorangpun dalam beribadat kepada Tuhannya" (QS. Al-Kahfi : 110).

Dengan pemaknaan di atas, dapat dipahami bahwa seluruh manusia akan mengalami proses reproduksi seksual dan senantiasa berupaya untuk memenuhi semua kebutuhan biologisnya, memerlukan ruang dan waktu, serta tunduk terhadap hukum alamiahnya (sunnatullah). Semuanya itu merupakan konsekwensi logis dari proses pemenuhan kebutuhan tersebut. Untuk itu Allah SWT memberikan kebebasan dan potensi yang dimilikinya untuk mengelola dan memanfaatkan alam semesta, sebagai salah satu tugas kekhalifahannya di muka bumi.

Kata al-basyar juga digunakan Allah SWT dalam Al-Quran untuk menjelaskan proses kejadian Nabi Adam AS, sebagai manusia pertama, yang memiliki perbedaan dengan proses kejadian manusia sesudahnya. Hal ini bisa terlihat dari firman Allah :
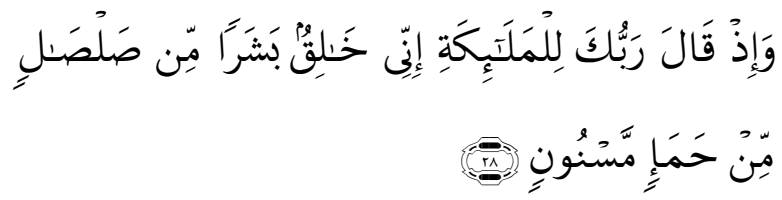

Dan (ingatlah), ketika Tuhanmu berfirman kepada Para Malaikat: "Sesungguhnya aku akan menciptakan seorang manusia dari tanah liat kering (yang berasal) dari lumpur hitam yang diberi bentuk. (QS. AlHijr : 28).
Dan juga dalam surat Shaad : 71, Allah berfirman :

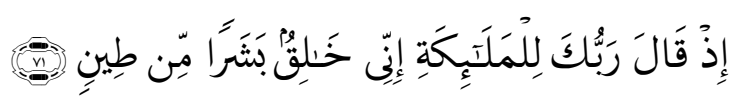

(ingatlah) ketika Tuhanmu berfirman kepada Malaikat: "Sesungguhnya aku akan menciptakan manusia dari tanah" (QS. Shaad : 71).

\section{Al-Insan}

Kata al-Insan yang berasal dari kata al-uns, dinyatakan dalam Al-Quran sebanyak 73 kali dan tersebar dalam 43 surat (Al-Baqi, 1988 : 119-120). Secara etimologi kata al-insan dapat diartikan harmonis, lemah lembut, tampak, atau pelupa.

Kata al-Insan digunakan dalam AlQuran untuk menunjukkan totalitas manusia sebagai makhluk jasmani dan rohani. Harmonisasi kedua aspek tersebut mengantarkan manusia sebagai makhluk Allah yang unik dan istimewa, sempurna, dan memiliki diferensiasi individual antara yang satu dengan yang lain, dan sebagai makhluk dinamis, sehingga mampu menyandang predikat khalifah Allah di muka bumi.

Perpaduan antara aspek fisik dan psikis telah membantu manusia untuk mengekspresikan dimensi al-insan albayan, yaitu sebagai makhluk berbudaya yang mampu berbicara, mengetahui baik dan buruk, mengembangkan ilmu pengetahuan dan peradaban, dan lain sebagainya. Dengan kemampuan ini, manusia akan dapat membentuk dan mengembangkan diri dan komunitasnya sesuai dengan nilai-nilai insaniah yang memiliki nuansa ilahiah yang hanif. Integralitas ini akan tergambar pada nilai iman dan amaliahnya, sebagaimana firman Allah :

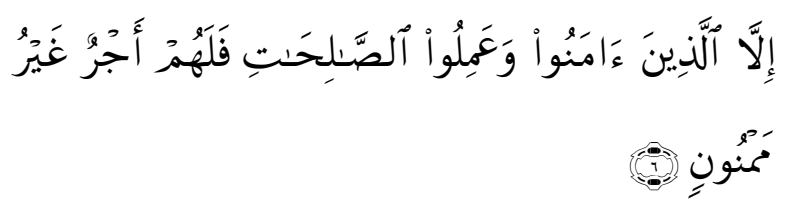


Artinya : Kecuali orang-orang yang beriman dan mengerjakan amal saleh; Maka bagi mereka pahala yang tiada putus-putusnya (QS. At-Tiin : 6).

Kata al-insan juga digunakan AlQuran untuk menjelaskan sifat umum, serta sisi kelebihan dan kelemahan manusia. Seperti firman Allah dalam surat Asy-Syuura : 48,

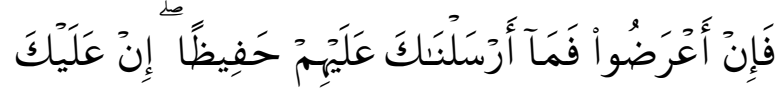

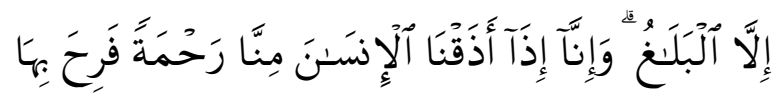

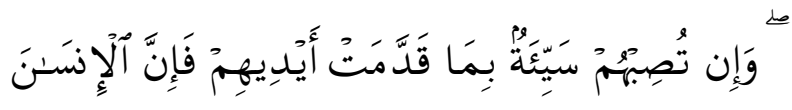

كَفُ

Artinya: Jika mereka berpaling Maka Kami tidak mengutus kamu sebagai Pengawas bagi mereka. kewajibanmu tidak lain hanyalah menyampaikan (risalah). Sesungguhnya apabila Kami merasakan kepada manusia sesuatu rahmat dari Kami Dia bergembira ria karena rahmat itu. dan jika mereka ditimpa kesusahan disebabkan perbuatan tangan mereka sendiri (niscaya mereka ingkar) karena Sesungguhnya manusia itu Amat ingkar (kepada nikmat). (QS. Asy-Syuura : 48).

Kata al-insan juga digunakan dalam Al-Quran untuk menunjukkan proses kejadian manusia sesudah Adam. Kejadiannya mengalami proses yang bertahap secara dinamis dan sempurna di dalam rahim, sebagaimana dalam Surat Al-Mu'minun : 12-14 :
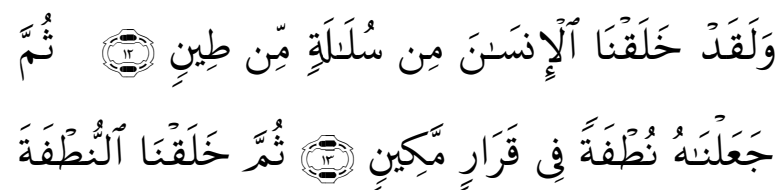

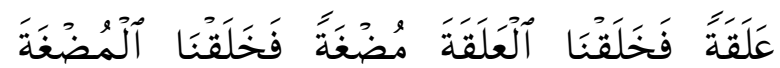

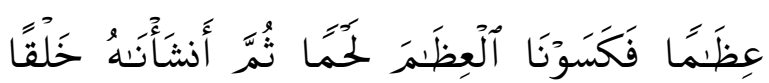

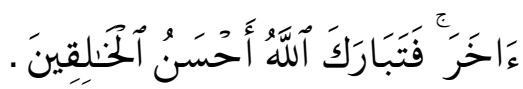

Artinya: Dan Sesungguhnya Kami telah menciptakan manusia dari suatu saripati (berasal) dari tanah. Kemudian Kami jadikan saripati itu air mani (yang disimpan) dalam tempat yang kokoh (rahim). Kemudian air mani itu Kami jadikan segumpal darah, lalu segumpal darah itu Kami jadikan segumpal daging, dan segumpal daging itu Kami jadikan tulang belulang, lalu tulang belulang itu Kami bungkus dengan daging. kemudian Kami jadikan Dia makhluk yang (berbentuk) lain. Maka Maha sucilah Allah, Pencipta yang paling baik (QS. AlMu'minun : 12-14).

Penggunaan kata al-Insan dalam ayat di atas mengandung dua makna, yaitu : Pertama, makna proses biologis, yaitu berasal dari saripati tanah melalui makanan yang di makan manusia, sampai pada proses pembuahan. Kedua, makna proses psikologis, yaitu proses ditiupkan ruh pada diri manusia, berikut berbagai potensi yang dianugerahkan Allah kepada manusia.

Makna pertama mengisyaratkan bahwa manusia pada dasarnya merupakan makhluk dinamis yang berproses dan tidak lepas dari pengaruh alam serta kebutuhan yang menyangkut dengannya. Keduanya saling mempengaruhi antara satu dengan yang lain. Sedangkan makna kedua mengisyaratkan bahwa, ketika manusia tidak bisa melepaskan diri dari kebutuhan materi dan berupaya untuk memenuhinya, manusia juga dituntut untuk sadar dan tidak melupakan tujuan akhirnya, yaitu kebutuhan immateri (sipritual). Untuk itu, manusia diperintahkan untuk senantiasa mengarahkan seluruh aspek amaliahnya padarealitas ketundukan pada Allah, tanpa batas, tanpa cacat, dan tanpa akhir. Sikap yang demikian akan senantiasa mendorong dan menjadikannya untuk cenderung berbuat kebaikan dan ketundukan pada ajaran Allah. 
Dari pemaknaan kata al-insan tersebut di atas, terlihat sesungguhnya manusia merupakan makhluk Allah yang memiliki sifat-sifat manusiawi yang bernilai positif dan negatif. Agar manusia bisa selamat dan mampu memfungsikan tugas dan kedudukannya di muka bumi dengan baik, maka manusia harus senantiasa mengarahkan seluruh aktifitasnya, baik fisik maupun psikis sesuai dengan nilai-nilai ajaran Islam.

\section{Al-Naas}

Kata al-Naas dinyatakan dalam AlQuran sebanyak 240 kali dan tersebar dalam 53 surat (Al-Baqi, 1988 : 895-899). Kata al-Naas, menurut Al-Isfahany sebagaimana dikutip Ramayulis menunjukkan pada eksistensi manusia sebagai makhluk sosial secara keseluruhan, tanpa melihat status keimanan atau kekafirannya (Ramayulis\&Samsul Nizar, 2011: 54).

Dalam menunjuk makna manusia, kata al-Naas lebih bersifat umum bila dibandingkan dengan kata al-Insan. Keumuman tersebut dapat dilihat dari penekanan makna yang dikandungnya. Kata al-nas menunjuk manusia sebagai sebagai makhluk sosial dan kebanyakan digambarkan sebagai kelompok manusia tertentu yang sering melakukan kerusakan dan merupakan penghuni neraka, disamping iblis. Sebagaimana firman Allah :

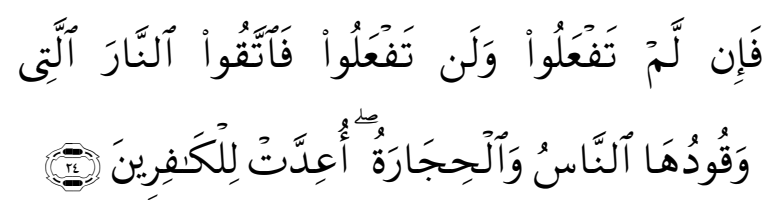

Artinya: Maka jika kamu tidak dapat membuat(nya) - dan pasti kamu tidak akan dapat membuat(nya), peliharalah dirimu dari neraka yang bahan bakarnya manusia dan batu, yang disediakan bagi orangorang kafir (QS. Al-Baqarah : 24).

Secara umum, penggunaan kata alNas memiliki arti peringatan Allah kepada manusia akan semua tindakannya, seperti : jangan bersifat kikir dan ingkar nikmat, riya (lihat QS. Al-Nisaa : 37-38), tidak menyembah dan meminta pertolongan selain pada Allah (lihat QS. Al-Maidah : 44), larangan berbuat dhalim (lihat QS AlA'raf : 85), mengingatkan manusia akan adanya ancaman dari kaum Yahudi dan Musyrik, semua amal manusia akan dibalas kelak di akherat.

\section{Bani Adam}

Kata bani Adam ditemukan sebanyak 7 kali dan tersebar dalam 3 surat. Secara etimologi kata bani Adam menunjukkan arti pada keturunan nabi Adam AS. Dalam ungkapan lain disebutkan dengan kata dzuriyat adam. Sebagaimana firman Allah :

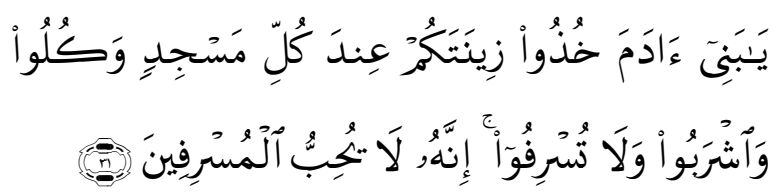

Artinya: Hai anak Adam, pakailah pakaianmu yang indah di Setiap (memasuki) mesjid, Makan dan minumlah, dan janganlah berlebih-lebihan. Sesungguhnya Allah tidak menyukai orangorang yang berlebih-lebihan (QS. Al-A'raaf: 31).

Dan pada firman Allah :

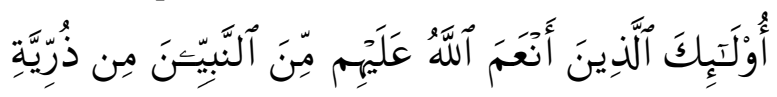

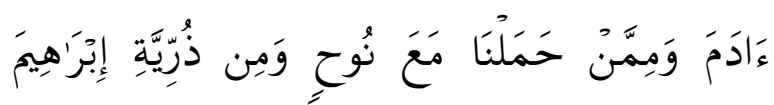

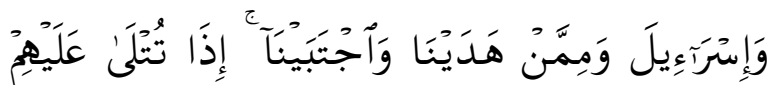

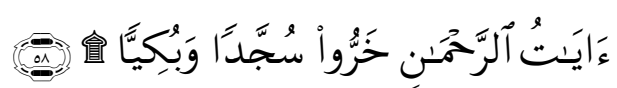

Artinya: Mereka itu adalah orang-orang yang telah diberi nikmat oleh Allah, Yaitu Para Nabi dari keturunan Adam, dan dari orang-orang yang Kami angkat bersama Nuh, dan dari keturunan Ibrahim dan Israil, dan dari orang-orang yang telah Kami beri petunjuk dan telah Kami pilih. apabila dibacakan ayat-ayat Allah yang Maha Pemurah kepada mereka, Maka mereka menyungkur dengan bersujud dan menangis (QS. Maryam : 58). 
Menurut

sebagimana dikutip oleh Ramayulis, penggunaan kata bani Adam menunjuk pada arti manusia secara umum. Dalam hal ini, setidaknya ada tiga aspek yang dikaji, yaitu : Pertama, anjuran untuk berbudaya sesuai dengan ketentuan Allah, diantaranya adalah dengan berpakaian guna menutup auratnya. Kedua, mengingatkan kepada keturunan Adam agar jangan terjerumus pada bujuk rayu syaitan yang mengajak pada keingkaran. Ketiga, memanfaatkan semua yang ada di alam semesta dalam rangka ibadah dan mentauhidkan Allah. Kesemuanya itu merupakan anjuran sekaligus peringatan Allah, dalam rangka memuliakan keturunan Adam dibandinkan makhlukNya yang lain (Ramayulis\&Samsul Nizar, 2011: 55).

Kata bani Adam tersebut lebih menekankan pada aspek amaliah manusia, sekaligus pemberi arah ke mana dan dalam bentuk apa aktifitas itu dilakukan. Pada dirinya diberikan kebebasan untuk melakukan serangkaian kegiatan dalam kehidupannya untuk memanfaatkan semua fasilitas yang ada di alam ini secara maksimal. Allah memberikan garis pembats kepada manusia pada dua alternatif, yaitu kemuliaan atau kesesatan. Di sini terlihat demikian kasih dan demokratisnya Allah terhadap manusia. Hukum kausalitas tersebut memungkinkan Allah untuk meminta pertanggung jawaban pada manusia atas semua aktivitas yang dilakukannya.

Konsep Islam dalam Al-Quran tentang hakekat manusia berdasarkan ungkapan kata al-basyar, al-insan, al-nas, dan bani adam atau dzuriyyat adam, sebagaimana disebutkan di atas, memberikan gambaran keseimbangan antara hak dan kewajiban manusia sebagai individu, sosil, budaya, dan makhluk Allah SWT. Kondisi demikian menempatkan manusia secara seimbang antara teosentris dan antroposentris.
Keseimbangan semacam ini, pada gilirannya terefleksi dalam penentuan nilai baik buruknya sifat/perbuatan manusia dapat dinilai secara syar'i dimana manusia tidak ikut campur. Misalnya tentang pahala dan dosa, halal dan haram, surga dan neraka.

Perbuatan manusia yang bernilai baik dipuji oleh Al-Quran, dan yang bernilai buruk dicela olehnya dan hal ini ditegaskan dalam berbagai ayat. Manusia dibebani kewajiban (taklif), maka manusia dapat menjadi makhluk yang berbuat baik dan dapat pula menjadi makhluk yang berbuat buruk. Terungkapnya nilai baik dan buruk yang dimungkinkan terdapat dalam diri manusia, menujukkan bahwa manusia disamping memiliki kelebihan dan keistimewaan, juga memiliki kelemahan dan kekurangan.

\section{Proses Penciptaan Manusia}

Dilihat dari proses penciptaanya, AlQuran menyatakan proses penciptaan manusia dalam dua tahapan yang berbeda, yaitu: Pertama, disebut dengan tahapan primordial. Dalam hal ini manusia pertama Adam AS diciptakan dari tanah (min tiin, min turob, min shal, min hamaain masnun), yang kemudian dibentuk oleh Allah dengan seindahindahnya, kemudian Allah meniupkan ruh dari-Nya ke dalam diri manusia (lihat QS. al-An'am: 2; QS. Al-Hijr: 26,28,29; QS. AlMukminun : 12; QS. Ar-Rum: 20; dan QS. Ar-Rahman: 4).

Kedua, disebut dengan tahapan biologi. Dalam proses ini manusia diciptakan dari inti sari tanah yang dijadikan air mani (nutfah) yang tersimpan dalam tempat yang kokoh (rahim). Kemudian nutfah itudijadikan darah beku ('alaqah) yang menggantung dalam rahim. Darah beku tersebut kemudian dijadikan-Nya segumpal daging (mudghah) dan kemudian dibalut dengan tulang belulang lalu kepadanya ditiupkan ruh. Sebagaimana firman Allah dalam surat Al-Mukminun ayat 12-14 : 


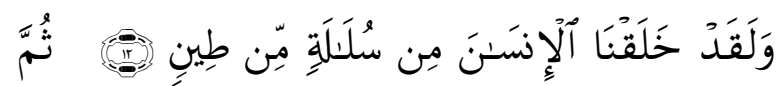

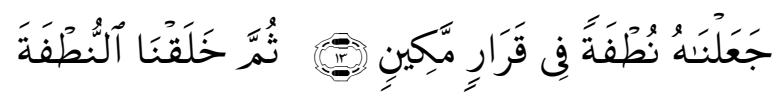

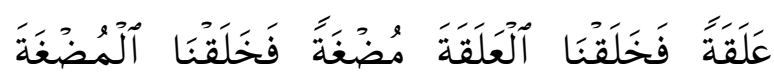
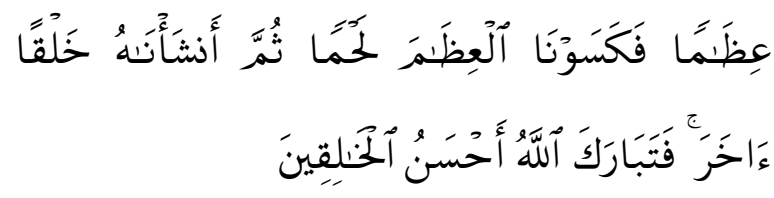

Artinya: Dan Sesungguhnya Kami telah menciptakan manusia dari suatu saripati (berasal) dari tanah. Kemudian Kami jadikan saripati itu air mani (yang disimpan) dalam tempat yang kokoh (rahim). Kemudian air mani itu Kami jadikan segumpal darah, lalu segumpal darah itu Kami jadikan segumpal daging, dan segumpal daging itu Kami jadikan tulang belulang, lalu tulang belulang itu Kami bungkus dengan daging. kemudian Kami jadikan Dia makhluk yang (berbentuk) lain. Maka Maha sucilah Allah, Pencipta yang paling baik (QS. AlMukminu : 12-14).

Berdasarkan proses penciptaan itu, manusia merupakan rangkaian utuh antara komponen materi dan immateri. Komponen materi berasal dari tanah, dan komponen immateri adalah ruh yang ditiupkan oleh Allah SWT. Kesatuan ini memberi makna bahwa di satu sisi manusia sama dengan dunia di luar dirinya (fana), dan di sisi lain mendakan bahwa manusia itu mampu mengatasi dunia sekitarnya, termasuk dirinya sebagai jasmani (baqa').

Menurut Harun Nasution, unsur materi manusia mempunyai daya fisik, seperti mendengar, melihat merasa, meraba, mencium dan daya gerak. Sementara itu unsur immateri mempunyai dua daya, yaitu daya berfikir yang disebut akal dan daya rasa yng berpusat di kalbu (Harun Nasution, 1995: 37).

dibina melalui membangun daya fisik perlu keterampilan danpanca indera. Sedangkan untuk mngembangkan daya akal dapat dipertajam melalui proses penalaran dan berfikir. Sedangkan untuk mengembangkan daya rasa dapat dipertajam melalui ibadah, karena intisari ibadah dalam Islam ialah mendekatkan diri kepada Allah SWT.

\section{Tugas dan Fungsi Manusia selaku Abdullah dan Khalifatullah.}

Kesatuan wujud manusia antara fisik dan psikis serta didukung oleh potensipotensi yang ada membuktikan bahwa manusia sebagai ahsan at-taqwim dan menempatkan manusia pada posisi yang strategis, yaitu : sebagai Hamba Allah (abdullah) dan Khalifah Allah (khalifah fi al-ardh).

\section{Manusia Sebagai Hamba Allah ('abdullah).}

Esensi dari 'abd adalah ketaatan, ketundukan dan kepatuhan yang kesemuanya itu hanya layak diberikan manusia kepada Allah SWT. Ketundukan dan ketaatan pada kodrat alamiah senantiasa berlaku bagi manusia. Ia terikat oleh hukum-hukum Allah yang menjadi kodrat pada setiap ciptaannya, manusia menjadi bagian dari setiap ciptaannya, dan ia bergantung pada pada sesamanya. Sebagai hamba Allah, manusia tidak bisa terlepas dari kekuasaan-Nya. Sebab manusia mempunyai fitrah (potensi) untuk beragama. Mulai dari manusia purba sampai kepada manusia modern sekarang yang mengakui bahwa diluar dirinya ada kekuasaan transendental (Ramayulis\&Samsul Nizar, ibid).

Hal ini disebabkan karena manusia adalah makhluk yang memiliki potensi untuk beragama sesuai dengan fitrahnya. Firman Allah SWT menyebutkan :

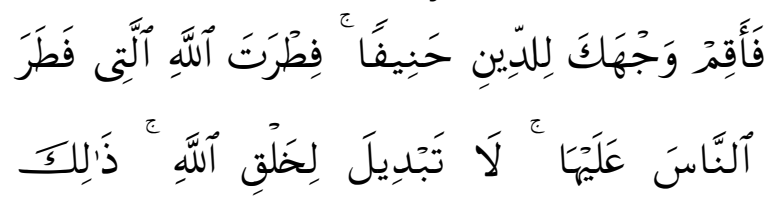




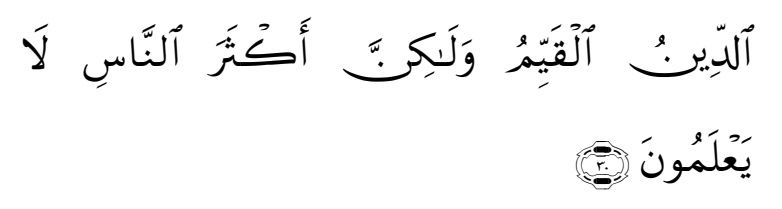

Artinya: Maka hadapkanlah wajahmu dengan Lurus kepada agama Allah; (tetaplah atas) fitrah Allah yang telah menciptakan manusia menurut fitrah itu. tidak ada peubahan pada fitrah Allah. (Itulah) agama yang lurus; tetapi kebanyakan manusia tidak mengetahui (QS. Ar-Ruum: 30).

Berdasarkan ayat di atas, semua suku bangsa manusia kapanpun dimanapun mengakui adanya Dzat Yang Maha Kuasa di luar dirinya. Allah SWT juga berfirman :

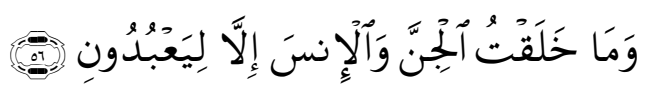

Artinya : Dan aku tidak menciptakan jin dan manusia melainkan supayamereka mengabdi kepada-Ku (QS. Al-Dzariaat : 56).

Berdasarkan ayat tersebut tergambarkan bahwa seluruh tugas manusia dalam hidup ini berakumulasi pada tanggung jawab mengabdi (beribadah) kepada Allah SWT. Pengakuan manusia akan adanya Allah secara naluriahmenurut informasi AlQuran disebabkan telah terjadinya dialog antara Allah dan roh manusia tatkala berada di alam arwah. Sebagaimana Firman Allah SWT :

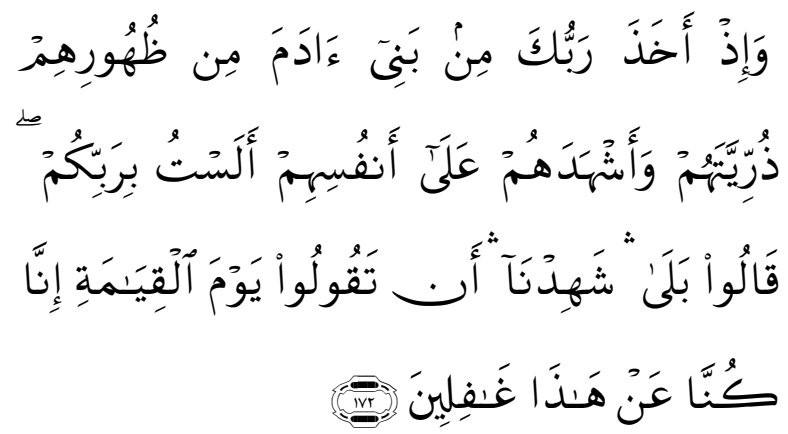

Artinya: Dan (ingatlah), ketika Tuhanmu mengeluarkan keturunan anak-anak Adam dari sulbi mereka dan Allah mengambil kesaksian terhadap jiwa mereka (seraya berfirman): "Bukankah aku ini Tuhanmu?" mereka menjawab: "Betul (Engkau Tuhan kami), Kami menjadi saksi". (kami lakukan yang demikian itu) agar di hari kiamat kamu tidak mengatakan: "Sesungguhnya Kami (Bani Adam) adalah orang-orang yang lengah terhadap ini (keesaan Tuhan)" (QS. Al-A'raaf : 172).

Dengan demikian, kepercayaan dan ketergantungan manusia dengan Tuhannya, tidak bisa dipisahkan dari kehidupan manusia. Karena manusia telah berikrar sejak di alam arwah bahwa Allah SWT adalah Tuhannya. Kepercayaan manusia kepada Dzat Yang Maha Agung yang ada di luar dirinya juga diiringi oleh kecenderungan yang tunduk dan patuh kepada-Nya. Kepatuhan tersebut kemudian dimanifestasikannya lewat peribadatan-peribadatan ritual sehingga manusia memiliki beban dan tugas sebagai makhluk pengabdi kepada Tuhannya (Ramayulis, 2011: 58-59).

Manusia sebagai hamba Allah ('abdullah) adalah makhuk yang dimuliakan olehAllah SWT. Kemuliaan manusia dibanding dengan makhluk lainnya adalah karena manusia dikaruniai akal untuk berfikir dan menimbang baikburuk, benar-salah, terpuji-tercela; sedangkan makhluklain semisal binatang, dan tumbuhan, tidaklah memperoleh kelebihan seperti halnya manusia. Selain itu, bentuk kejadian manusia adalah yang paling baik. Allah SWT berfirman :

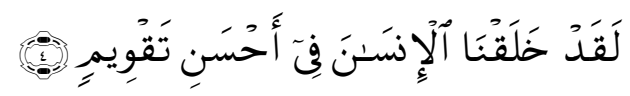

Artinya: Sesungguhnya Kami telah menciptakan manusia dalam bentuk yang sebaik-baiknya (QS. At Tin : 4).

Kesadaran manusia bahwa ia hidup di dunia sebagai hamba Allah, menumbuhkan sikap mawas diri bahwa dirinya bukan Tuhan, oleh sebab itu melihat sesama manusiaa sebagai sesama makhluk, tidak ada perhambaan antar sesama manusia (Assegaf, 2011:159). 


\section{Manusia Sebagai Khalifah Allah}

Kata khalifah berasal dari kata khalafa, yang berarti mengganti atau melanjutkan. Menurut Quraish Shihab, istilah khalifah dalam bentuk mufrad (tunggal) berarti penguasa politik dan religius. Istilah ini digunakan untuk nabinabi dan tidak digunakan untuk manusia pada umumnya. Sedangkan untuk manusia biasa digunakan khala'if yang di dalamnya mengandung makna yang lebih luas, yaitu bukan hanya sebagai penguasa dalam berbagai bidang kehidupan (Shihab, 1994: 69-70).

Untuk mendapatkan gambaran yang lebih dalam tentang fungsi kekhalifahan di alam ini, dapat dilihat dalam beberapa ayat berikut ini :

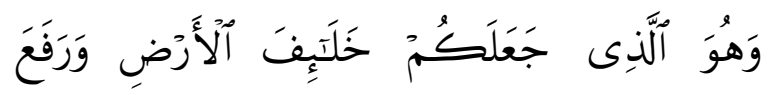

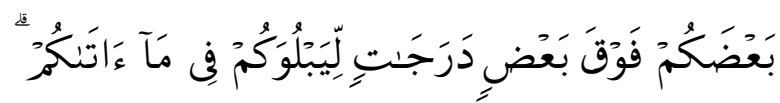

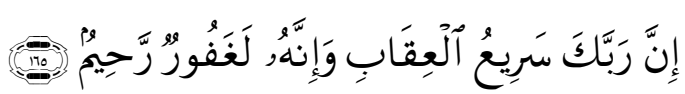

Artinya: Dan Dia lah yang menjadikan kamu penguasa-penguasa di bumi dan Dia meninggikan sebahagian kamu atas sebahagian (yang lain) beberapa derajat, untuk mengujimu tentang apa yang diberikan-Nya kepadamu. Sesungguhnya Tuhanmu Amat cepat siksaan-Nya dan Sesungguhnya Dia Maha Pengampun lagi Maha Penyayang (QS. Al-An'am : 165).

Pada ayat yang lain juga dapat disebutkan :

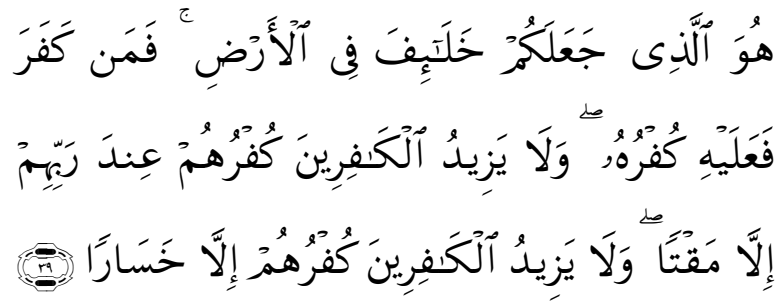

Artinya: Dia-lah yang menjadikan kamu khalifah-khalifah di muka bumi. Barangsiapa yang kafir, Maka (akibat) kekafirannya menimpa dirinya sendiri. dan kekafiran orang-orang yang kafir itu tidak lain hanyalah akan menambah kemurkaan pada sisi Tuhannya dan kekafiran orangorang yang kafir itu tidak lain hanyalah akan menambah kerugian mereka belaka (QS. Fathir : 39).

Pada ayat berikut ini juga dijelaskan :

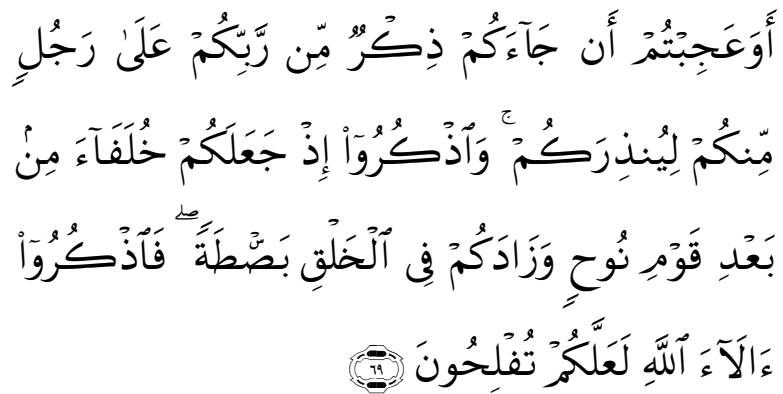

Artinya: Apakah kamu (tidak percaya) dan heran bahwa datang kepadamu peringatan dari Tuhanmu yang dibawa oleh seorang laki-laki di antaramu untuk memberi peringatan kepadamu? dan ingatlah oleh kamu sekalian di waktu Allah menjadikan kamu sebagai penggantipengganti (yang berkuasa) sesudah lenyapnya kaum Nuh, dan Tuhan telah melebihkan kekuatan tubuh dan perawakanmu (daripada kaum Nuh itu). Maka ingatlah nikmat-nikmat Allah supaya kamu mendapat keberuntungan. (QS. AlA'raf : 69).

Ayat-ayat tersebut di atas, disamping menjelaskan kedudukan manusia di alam raya sebagai khalifah dalam arti yang luas, juga memberi isyarat tentang perlunya sikap moral atau etika yang harus ditegakkan dalam melaksanakan fungsi kekhalifahannya.

Qurais Shihab mengatakan bahwa hubungan antara manusia dengan alam atu hubungan manusia dengan sesamanya, bukan merupakan hubungan antara penakluk dengan yang ditaklukkan, atau antara tuan dengan hamba, akan tetapi hubungan kebersamaan dalam ketundukan kepada Allah SWT. Sebab meskipun manusia mampu mengelola, namun hal tersebut bukan akibat kekuatan yang dimilikinya, tetapi akibat Allah menundukkannya untuk manusia. Oleh karena itu, manusia dalam visi kekhalifahannya, bukan saja sekedar 
menggantikan, namun dengan arti yang luas ia harus senantiasa mengikuti perintah yang digantikannya yaitu Allah SWT.

Dalam melaksanakan tugasnya sebagai khalifah, Allah SWT telah memberikan kepada manusia seperangkat potensi (fitrah) berupa Aql, qalb, dan nafs. Namun demikian aktualisasi fitrah tersebut tidak otomatis berkembang, melainkan tergantung pada manusia itu sendiri mengembangkannya. Untuk itu, Allah SWT menurunkan wahyu-Nya kepada para Nabi, agar menjadipedoman bagi manusia dalam mengaktualisasikan fitrahnya secara utuh dan selaras dengan tujuan penciptaannya. Dengan pedoman ini manusia akan dapat tampil sebagai mahkluk Allah yang tinggi martabatnya, dan sebaliknya jika tidak, ia akan rendah martabatnya yang sama esensinya dengan hewan.

Ahmad Hasan Firhat sebagaimana dikutip oleh Ramayulis membedakan kedudukan kekhalifahan manusia pada dua bentuk, yaitu : Pertama, khalifah kauniyah. Dimensi ini mencakup wewenang manusia secara umum yang telah dianugerahkan Allah SWT untuk mengatur dan memanfaatkan alam semesta beserta isinya bagi kelangsungan kehidupan umat manusia di muka bumi. Pemberian wewenang Allah SWT kepada manusia dalam konteks ini, meliputi pemaknaan yang bersifat umum, tanpa dibatasi oleh agama apa yang mereka yakini. Artinya, label kekhalifahan yang dimaksud diberikan kepada semua manusia sebagai penguasa alam semesta.

Kedua, khalifah syar'iyah. Dimensi ini merupakan wewenang Allah SWT yang diberikan kepada manusia untuk memakmurkan alam semesta. Hanya saja, untuk melaksanakan tugas dan tanggung jawab ini, predikat khalifah secara khusus ditujukan kepada orang-orang mukmin. Hal ini dimaksudkan, agar dengan keimanan yang dimilikinya, mampu menjadi pilar dan kontrol dalam mengatur mekanisme alam semesta, sesuai dengan nilai-nilai ilahiyah yang telah digariskan Allah lewat ajaran-Nya. Dengan prinsip ini, manusia akan senantiasa berbuat kebaikan dan memanfaatkan alam semesta demi kemaslahatan umat manusia.

Sebagai khalifah, manusia muslim dimaksudkan tampil di bumi ini dengan wajahnya yang ramah dan anggun untuk memimpin, mengelolan dan memakmurkan bumi, bukan sebaliknya sebagai orang yang tertindas, dan terbelakang dari berbagai kemajuan (Assegaf, 2011: 162).

Untuk mencapai yang demikian itu, pendidikan Islam diharapkan mampu memberdayakan funsi khalifah dalam langkah-langkah yang kongkret. Bila hal tersebut tidak dilakukan, maka fungsi khalifah tadi dapat diambilalih oleh manusia dan golongan yang lain.

\section{IMPLIKASI PADA PENDIDIKAN ISLAM}

Para ahli pendidikan muslim pada umumnya sependapat bahwa teori dan praktek kependidikan Islam harus didasarkan pada konsepsi dasar tentang manusia. Pembicaraan diseputar persoalan ini adalah merupakan sesuatu yang sangat vital dalam pendidikan. Tanpa kejelasan tentang konsep ini, pendidikan akan meraba-raba, dan bahkan bisa jadi pendidikan Islam tidak akan dapat dipahami secara jelas tanpa terlebih dahulu memahami konsep Islam yang berkaitan dengan pengembangan individu seutuhnya.

Identitas manusia muslim secara sempurna dapat diperoleh setelah fungsinya sebagai makhluk, pendidik dan si terdidik, hamba Allah ('abd) dan khalifah Allah, serta potensi lainnya benar-benar telah dilakukan integrasi secara seimbang dalam kesatuan yang utuh. Penekanan pada salah satunya sembari meninggalkan yang lain berakibat tidak sempurnanya identitas manusia 
sebagai insan kamil atau muslim kaffah (Assegaf, 2011: 163).

Bila pendidikan Islam semata-mata menekankan pembentukan pribadi muslim yang sanggup mengabdi, beribadah, dan berakhlak karimah, akibatnya pribadi yang terbentuk adalah kesalehan individual yang mengabaikan penguasaan ilmu pengetahuan dan teknologi, dan bisa dipastikan kemajuan ilmu pengetahuan dan teknologi akan diambil oleh umat yang lain.

Begitu juga sebaliknya, bila pendidikan Islam hanya memfokuskan perannya sebagai pembentuk khalifah di muka bumi yang sanggup menguasai ilmu dan teknologi dan menguak rahasia alam untuk dikelola demi kemakmuran hidup di dunia, tanpa memberi keseimbangan terhadap fungsinya sebagai hamba Allah SWT, maka manusia bisa pandai, tetapi jiwa dan hatinya kosong dari cahaya ilahi.

Dari uraian terdahulu tentang hakekat manusia dalam konsep Islam, dapat dilihat implikasi penting konsep terbsebut dalam hubunganya dengan pendidikan Islam, yaitu:

Pertama, sudah diketahui bahwa manusia adalah makhluk yang memiliki dua komponen materi dan immateri (jasmani dan rohani), maka konsepsi itu menghendaki proses pembinaan yang mengacu ke arah realisasi dan pengembangan komponen-komponen tersebut. Hal ini berarti bahwa sistem pendidikan Islam harus dibangun di atas konsep kesatuan (integrasi) antara pendidikan qalbiyah dan aqliyah sehingga mampu menghasilkan manusia muslim yang pintar secara intelektual danterpuji secara moral. Jika kedua komponen itu terpisah atau dipisahkan dalam proses kependidikan Islam, maka manusia akan kehilangan keseimbangannya dan tidak akan pernah menjadi pribadi-pribadi yang sempurna (insan kamil).

Kedua, Al-quran menjelaskan bahwa fungsi penciptaan manusia di alam ini adalah sebagai khalifah dan 'abd. Untuk melaksanakan fungsi ini Allah SWT membekali manusia dengan seperangkat potensi. Dalam konteks ini, maka pendidikan Islam harus merupakan upaya yang ditujukan ke arah pengembangan potensi yang dimiliki manusia secara maksimal, sehingga dapat diwujudkan dalam bentuk kongkrit, dalam kompetensi-kompetensi yang bermuatan hard skill dan soft skill.

Ketiga, fungsionalisasi pendidikan Islam dalam mencapai tujuannya sangat bergantung kepada sejauh mana kemampuan umat Islam menterjemahkan dan merealisasikan konsep tentang hakekat manusia dan fungsi penciptaanya dalam alam semesta ini. Dalam hal ini, pendidikan Islam harus dijadikan sarana yang kondusif bagi proses transformasi ilmu pengetahuan dan budaya Islami dari satu generasi kepada generasi berikutnya. Posisi manusia sebagai khalifah dan 'abd menghendaki program pendidikan yang menawarkan sepenuhnya penguasaan ilmu pengetahuan secara totalitas, agar manusia tegar sebagai khalifah dan taqwa sebagai dari aspek 'abd.

Keempat, agar pendidikan Islam berhasil dalam prosesnya, maka konsep hakekat manusia dan fungsi penciptaannya dalam alam semesta harus sepenuhnya diakomodasikan dalam perumusan teori-teori pendidikan Islam melalui pendekatan kewahyuan, empirik keilmuan dan rasional filosofis. Dalam hal ini harus difahami pula bahwa pendekatan keilmuan dan filosofis hanya merupakan media untuk menalar pesan-pesan Allah yang absolut, baik melalui ayat-ayat-Nya yang bersifat tekstual (quraniyah), maupun ayat-ayat-Nya yang bersifat kontekstual (kauniyah), yang telah dijabarkan-Nya melalui sunnatullah.

Kelima, proses internalisasi nilainilai Islam kedalam invividu atau pribadi seseorang harus dapat dipadukan melalui peran individu maupun orang lain (guru), sehingga dapat meperkuat terwujudnya kesatuan pola dan kesatuan tujuan 
menuju terbentuknya mentalitas yang sanggup mengamalkn nilai dan norma Islam dalam diri insan kamil (Arifin, 2010: 158).

\section{PENUTUP}

Hakekat manusia dalam konsep Islam adalah makhluk yang diciptakan oleh Allah SWT, memiliki berbagai potensi untuk tumbuh dan berkembang menuju kesempurnaan ciptaan sesuai dengan yang dikehendaki oleh Sang Pencipta. Dalam Al-Quran menyebutkan manusia dengan berbagai kata yaitu : al-Basyar, AlInsan, Al-Nas, dan Bani Adam atau Durriyat Adam.

Sebagai makhluk yang diciptakan Allah SWT, manusia mempunyai tugas dan fungsi sebagai hamba Allah (abdullah) dan khalifah Allah di muka bumi. Sebagai hamba Allah (abdullah) setiap manusia dituntut untuk menjadikan seluruh aktifitas hidupnya sebagai manifestasi dari ketundukan dan pengabdian kepada Allah SWT.

Sebagai khalifah Allah, setiap
manusia diberikan Allah segala
kemampuan untuk mengolah dan
memakmurkan bumi serta isinya, guna
memenuhi segala kebutuhan hidupnya,
yang dilakukan dengan senantiasa
menjaga keseimbangan alam semesta dan
menjaga kelestarian alam serta makhluk
hidup lainya yang akhirnya
diorientasikannyauntuk beribadah.
Implikasi penting konsep Islam
tentang hakekat manusia dalam
hubunganya dengan pendidikan Islam,
adalah : pertama : sistem pendidikan
Islam harus dibangun di atas konsep
kesatuan (integrasi) antara pendidikan
qalbiyah dan aqliyah sehingga mampu
menghasilkan manusia muslim yang
pintar secara intelektual danterpuji secara
moral. Kedua : pendidikan Islam harus
merupakan upaya yang ditujukan ke arah
pengembangan potensi yang dimiliki
manusia secara maksimal, sehingga dapat
diwujudkan dalam bentuk kongkrit, dalam

kompetensi-kompetensi yang bermuatan hard skill dan soft skill. Ketiga : pendidikan Islam harus dijadikan sarana yang kondusif bagi proses transformasi ilmu pengetahuan dan budaya Islami dari satu generasi kepada generasi berikutnya. Keempat : konsep hakekat manusia dan fungsi penciptaannya dalam alam semesta harus sepenuhnya diakomodasikan dalam perumusan teori-teori pendidikan Islam melalui pendekatan kewahyuan, empirik keilmuan dan rasional filosofis. Kelima : proses internalisasi nilai-nilai Islam kedalam invividu atau pribadi seseorang harus dapat dipadukan melalui peran individu maupun orang lain (guru), sehingga dapat meperkuat terwujudnya kesatuan pola dan kesatuan tujuan menuju terbentuknya mentalitas yang sanggup mengamalkn nilai dan norma Islam dalam diri insan kamil.[] 


\section{DAFTAR RUJUKAN}

Al-Abrasy, M. Athiyah. Dasar-Dasar Pokok Pendidikan Islam, Jakarta: Bulan Bintang, 1970.

Al-Baqi, Fu'ad Abdul. Al-Mu'jam AlMufahras li Al-Alfaz Al-Quran LaKarim, Qahirah: Dar Al-Hadits, 1988.

Arifin, Muzayyin. Filsafat Pendidikan Islam, Jakarta: Bumi Aksara., 2010.

Assegaf, Abd Rahman. Filsafat Pendidikan Islam, Jakarta: Raja Grafindo Persada, 2011.

Daradjat, Zakiah. Ilmu Pendidikan Islam, Jakarta: Bumi Aksara, 1992.

Ibn Munzhir. Lisan Al-Arab, Mesir: Dar AlMishriyah, Juz VII, 1992.

Jalaluddin \& Usman Said. Filsafat Pendidikan Islam, Jakarta: Raja Grafindo Persada, 1996.

Nasution, Harun. Islam Rasional, Bandung: Mizan, 1995.

Ramayulis dan Samsul Nizar. Filsafat Pendidikan Islam: Telaah Sistem Pendidikan Islam dan Pemikiran Para Tokohnya, Jakarta: Kalam Mulia, 2011.

Shihab, M. Quraish. Membumikan AlQuran, Bandung: Mizan, 1994.

Shihab, M. Quraish. Tafisr Al mishbah (Pesan, Kesan dan keserasian AlQur'an) volume 7, Jakarta: Lentera Hati, 2002.

Tafsir, Ahmad. Ilmu Pendidikan Dalam Perspektif Islam, Bandung: Remaja Rosdakarya, 1994.

Uhbiyati, Nur. Ilmu Pendidikan Islam I, Bandung: Pustaka Setia, 1998. 